\title{
Strategie oswajania rzeczy na „Ziemiach Odzyskanych" ze szczególnym uwzględnieniem przestrzeni prywatnej
}

\begin{abstract}
Strategies of the Familiarization of Things in Polish Regained Territories (with the Special Attention to the Private Space). This article discusses the presence of things and their modes of functioning in the private (and, to some extent, also public) spaces of the Recovered Territories in Poland after the Second World War. In this article, things are perceived as active agents, crucial for developing many different social relations that have to be created anew in the unknown cultural and material environment. New things that people come across are also treated here as objects that can reveal traumatic tensions caused by the necessity of the existence in the unfamiliar space that was left behind by the war enemies. This new private space that the Polish people have to live in needs to be domesticated and treated as a part of the everyday life. Strategies that are used to familiarize the former German cultural heritage are the main focus of this article.
\end{abstract}

Keywords: things, trauma, migration, Regained Territories

Стратегии осваивания вещей на воссоединённых землях Польши (особенно в личном пространстве). В этой статье представлена проблема присудствия вещей и способа их функционирования особенно в личном пространстве на воссоединённых землях Польши после второй мировой войны. Вещи выступают здесь как активные актёры многих разнообразных общественных соотношений, которые надо создать заново в незнакомой материальной и культурной среде. Одновременно новонайденные предметы могут вызывать травматические реакции у переселенцев, которые

Adres do korespondencji: Instytut Historii UAM, ul. Umultowska 89d, 61-614 Poznań. E-mail: praczyk@amu.edu.pl. 
возникают как результат необходимости жизни в домах покиданных врагом. Это новое пространство должно быть освоенное новыми жителями. Меtоды ведущие к этой цели являются темой представленного здесь анализа.

Ключевые слова: вещи, травма, пространство, миграция, воссоединённые земли

W niniejszym artykule proponuję spojrzenie na doświadczenia Polaków migrujących na tereny tzw. Ziem Odzyskanych po II wojnie światowej, dowartościowując i włączając nie-ludzkie podmioty, w tym wypadku rzeczy, do opisu ludzkich zmagań tamtej doby. Przyłączam się tym samym do wielokrotnie już powtarzanej i uznanej tezy o sprawczości nie-ludzi, w tym rzeczy ${ }^{1}$, i pragnę podkreślić wagę znaczenia materialności w kontekście ludzkiego doświadczenia. Przykłady, którymi zamierzam się posłużyć, pochodzą z osobistych relacji osadników, zgromadzonych w tomach pamiętników. Korzystałam też z publikowanych wyników badań etnograficznych prowadzonych przez poznańskich etnologów w rejonie Nadodrza²

Dyskurs migracyjny rzadko opisywany jest w kategoriach traumy wynikającej z nieustannej konieczności przemieszczania się, ciągłego porzucania i nabywania rzeczy, z których najczęściej tylko garstka (a i to nie zawsze) pochodzi z miejsca, z którego wyruszono. W badaniach historii migracji w kontekście „Ziem Odzyskanych" nie dostrzega się też wystarczająco problemów wykorzenienia i ciągłej próby zakorzenienia w nowej rzeczywistości. Wynikają one ze zmagania się z „obcymi” przedmiotami, które otaczają migrantów w punkcie dojścia, lub z braku tych, które utracono, opuszczając rodzinne strony ${ }^{3}$. Interesująca i godna uwagi wydaje się

1 Zob. m.in. B. Latour, Splatając na nowo to społeczne: wprowadzenie do teorii aktora-sieci, tłum. A. Derra, K. Abriszewski, Kraków 2010; idem, From realpolitik to dingpolitik or how to make things publick, [w:] Making Things Public. Atmosphere of Democracy, red. B. Latour, P. Weibel, MassachusettsKarlsruhe 2005, s. 4-31; Rzeczy i ludzie. Humanistyka wobec materialności, red. J. Kowalewski, W. Piasek, M. Śliwa, Olsztyn 2007; B. Mądra-Shallcross, Rzeczy i Zagłada, Kraków 2010.

2 Pamiętniki osadników Ziem Odzyskanych, red. Z. Dulczewski, A. Kwilecki, Poznań 1970. Opublikowane po raz pierwszy w 1963 roku pamiętniki są przedmiotem kontrowersji wynikającej z ingerencji w ich treści, które podyktowane były cenzurą i polityką historyczną doby PRL-u. Jednak dla interesujących mnie tu problemów - opisów obcowania z rzeczami - fakt ten nie ma zasadniczego znaczenia. W związku z powyższym opublikowane pamiętniki stanowią wiarygodne źródło dla analiz zaprezentowanych w poniższym artykule. Pamiętniki opublikowane przez Beatę Halicką stanowią w części powielenie wspomnień opublikowanych w roku 1970, uzupełnionych o kilka nowych, wcześniej niepublikowanych tekstów (Mój dom nad Odrą. Pamiętniki osadników Ziem Zachodnich po 1945 roku, red. B. Halicka, Kraków 2016). Na temat badań etnograficznych dotyczących „Ziem Odzyskanych” zob. Z. Jasiewicz, Badania na ziemiach zachodnich i pótnocnych i ich znaczenie dla etnologii polskiej, [w:] Polska-Niemcy. Pogranicze kulturowe i etniczne, red. M. Buchowski, A. Brencz, Wrocław-Poznań 2004.

${ }^{3}$ Brakuje monografii poświęconej tematyce oswajania niemieckiej spuścizny materialnej w przestrzeni prywatnej. Kluczowe pozycje zawierające zbiory artykułów dotyczące tzw. Ziem Odzyskanych poświęcają uwagę głównie niemieckiemu dziedzictwu kulturowemu w planie publicznym. Zob. przede wszystkim Wokół niemieckiego dziedzictwa kulturowego na Ziemiach Zachodnich i Pótnocnych, red. Z. Mazur, Poznań 1997; Wspólne dziedzictwo? Ze studiów nad stosunkiem do spuścizny kulturowej na Ziemiach Zachodnich i Pólnocnych, red. Z. Mazur, Poznań 2000. 
tu $\mathrm{z}$ jednej strony kwestia bycia $\mathrm{w}$ drodze, wiążąca się z lękiem o przyszłość oraz $\mathrm{z}$ faktem permanentnego znajdowania się w liminalnej fazie przejścia i obcowania $\mathrm{z}$ przedmiotami, które są nieustannie wymieniane, w większości są nabywane jed nie przejściowo, na określony, zazwyczaj bardzo krótki, czas.

Szczególnie interesujące wydaje mi się jednak to, co dzieje się z człowiekiem, który osiedla się już ostatecznie w nowym przestrzennym kontekście, gdzie zmuszony jest do oswojenia nowej, obcej przestrzeni prywatnej oraz publicznej jako takiej, która stanowi dla niego nowy kontekst społecznego funkcjonowania. Co więcej, w tym wypadku jest to przestrzeń wcześniej wytworzona i zamieszkiwana przez kogoś, kto w rezultacie wojny okazał się wrogiem. Już w punkcie wyjścia nacechowana jest ona zatem koniecznością skonfrontowania się z przedmiotami, które przynajmniej w części skazane są na wykluczenie z życia społecznego nowych mieszkańców, na zniszczenie i zatarcie.

Przybysz musi jednak tę obcą przestrzeń oswoić, co jest szczególnie trudne, bo jest to jednocześnie przestrzeń uprzedniego wroga, którego ludzki wymiar, reprezentowany przez rzeczy, zaprzecza jego absolutnej obcości. Taką właśnie przestrzeń trzeba oswoić i w niej zamieszkać. To ona musi stać się przestrzenią osobistą i przyjazną dla nowoprzybyłych. W związku z tym oswajanie odbywa się na dwóch wspomnianych, podstawowych płaszczyznach: $z$ jednej strony dotyczy ono wtargnięcia $\mathrm{w}$ cudzą przestrzeń prywatną, z drugiej — zaistnienia w przestrzeni publicznej. Fakt ten rodzi problemy wynikające $\mathrm{z}$ konieczności funkcjonowania między pozostawionymi przez Niemców przedmiotami (meble, książki, urządzenia, ale też niejednokrotnie są to przedmioty osobiste, takie jak albumy ze zdjęciami) oraz niemożności wystarczającego wypełnienia owej przestrzeni swoimi rzeczami, pozostawionymi w porzuconych, rodzinnych domach. $Z$ drugiej strony oswojenia wymaga cały kontekst przestrzenny, w którym znaleźli się przesiedleńcy. Wiąże się on z inną infrastrukturą, innymi układami urbanistycznymi czy wszelkimi znakami znajdującymi się w przestrzeni publicznej miast oraz wsi, które świadczą o obcości kulturowej nowo zamieszkałych obszarów. W jaki sposób udomawiano miejsca, w których przyszło żyć przesiedleńcom? Jakie problemy rodziło życie między obcymi rzeczami?

\section{Migracje Polaków i Niemców}

Okres II wojny światowej oraz czas zaraz po jej zakończeniu charakteryzowały $\mathrm{m}$ in. ciągłe migracje ludności. Podaje się liczbę nawet $60 \mathrm{mln}$ ludzi migrujących przymusowo w latach 1939-1945, a przesiedlenia ludności polskiej i niemieckiej w końcu wojny i bezpośrednio po niej w konsekwencji zmian granic w Europie Środkowej szacuje się na $8,5 \mathrm{mln}^{4}$. Na terenie Polski szczególnie nasiliły się one zaraz

${ }^{4}$ D. Stola, Wielkie migracje w Europie XX wieku, [w:] Cywilizacja europejska. Eseje i szkice z dziejów cywilizacji i dyplomacji, red. M. Koźmiański, Warszawa 2010, s. 360-364. 
po wojnie (1945-1946). Wiązało się to z masowymi przesiedleniami ludności niemieckiej z wcześniejszych, wschodnich terenów Niemiec na Zachód oraz ludności polskiej z kresowych obszarów włączanych systematycznie do ZSRR na tzw. Ziemie Odzyskane ${ }^{5}$. Decyzje o masowych przesiedleniach Polaków i Niemców podejmowano na konferencjach w Jałcie i Poczdamie. W Jałcie zadecydowano o włączeniu Kresów Wschodnich w obręb Związku Radzieckiego i o przyłączeniu do Polski Ziem Zachodnich i Północnych. Ostatecznie decyzja ta została przypieczętowana na mocy ustaleń z konferencji poczdamskiej. Wtedy zadecydowano bowiem m.in. o przesiedleniu ludności niemieckiej z terenów Polski (ale też Czechosłowacji i Węgier) i o wytyczeniu nowej, zachodniej granicy Polski. Z obszarów, które po wojnie znalazły się w granicach Polski, w przeciągu pięciu lat po wojnie wysiedlono $3,5 \mathrm{mln}$ ludzi. Z Kresów oraz Polski centralnej na tereny Ziem Północnych i Zachodnich przybyło natomiast około 1,8 mln ludzi.

Owe masowe ruchy ludności skutkowały nie tylko ogromnymi problemami w sferze politycznej, społecznej czy organizacyjnej, lecz wymagały także wielkiej mobilizacji poszczególnych jednostek zarówno na płaszczyźnie materialnej, jak i psychologicznej. Wspomniane tu trudności dotyczące organizacji czy mobilizacji w dużej mierze związane były natomiast właśnie z rzeczami.

\section{Strategie oswajania}

Sposoby oswajania przestrzeni, w której znaleźli się Polacy na tzw. Ziemiach Odzyskanych, odbywały się, jak wspomniałam, w sferze prywatnej oraz w sferze publicznej. W obu wypadkach należy jednak wprowadzić jeszcze rozróżnienie dotyczące nowo zamieszkałych obszarów: inaczej bowiem problem ten kształtował się na wsi, inaczej natomiast w mieście. Z przeanalizowanych przeze mnie relacji osadników wynika, że oswajanie takie odbywało się za pomocą kilku odmiennych praktyk, spośród których w jasny sposób wyłaniają się następujące strategie: niszczenia, wymiany, udomowienia oraz ignorowania zastanych przedmiotów ${ }^{6}$.

W wypadku przestrzeni prywatnej zamieszkanie obcych domów oznaczało w pierwszej kolejności właśnie oswojenie obcego miejsca. Jeżeli zamieszkiwano domy bądź mieszkania, które nie zostały wcześniej ograbione, podejmowano decyzje dotyczące tego, które rzeczy pozostawić, a których się pozbyć. Pozbywano się przede wszystkim rzeczy osobistych, takich jak książki w języku niemieckim czy albumy ze zdjęciami. Przedmioty te były po prostu niepotrzebne bądź też służyły jako materiał grzewczy — książkami palono w piecach. Niekiedy jednak przedmioty takie wtórnie

${ }^{5}$ J. Misztal, Wysiedlenia i repatriacja obywateli Polskich z ZSRR a wysiedlenia i przesiedlenia Niemców z Polski - próba bilansu, [w:] Utracona ojczyzna, red. H. Orłowski, A. Sakson, Poznań 1996, s. $45-74$.

${ }^{6}$ Na temat oswajania przestrzeni „Ziem Odzyskanych” zob. też B. Halicka, Polski Dziki Zachód. Przymusowe migracje i kulturowe oswajanie Nadodrza 1945-1958, Kraków 2015, s. 235-241. 
traumatyzowały, przywołując pamięć o wrogu, który — jak dowodziły przedmioty - miał swą prywatną przestrzeń, wypełnioną rzeczami, z którymi był związany podobnie jak ci, którzy przybyli, a wcześniej zmuszeni byli do porzucenia swojego osobistego dobytku. Konfrontacja ze zwyczajnym człowieczeństwem Niemców, którego emanacją były rzeczy, uniwersalizowała doświadczenie krzywdy i utraty, a to dawało efekt traumatyczny. W takim wypadku należało pozbyć się owych osobistych przedmiotów bądź włączyć je we własną historię, nadając im nową tożsamość.

Jeżeli przyjmiemy w najogólniejszym planie, że trauma stanowi reakcję na tragiczne wydarzenie czy wydarzenia, którym nie można sprostać wtedy, gdy następują, i w konsekwencji stanowi ona to, co nie do końca rozpoznane, niewypowiedziane, o czym nie można mówić, bo nie istnieje język, którym można tę traumę wypowiedzieć, to podejmowanie działań wobec rzeczy stanowi „wentyl bezpieczeństwa” i potencjalną szansę wyrażenia traumy i przepracowywania traumatycznego doświadczenia ${ }^{7}$. Rzeczy będące znakiem obcej obecności przywołują z opóźnieniem pamięć o przeżytym traumatycznym doświadczeniu i umożliwiają jego odreagowanie w bezpiecznych warunkach pełnej kontroli.

Jedną ze strategii było więc „odgrywanie się" na rzeczach i niszczenie ich. Dotyczyło to zarówno obiektów znajdujących się w gestii publicznej, jak i osobistych przedmiotów pozostawionych przez Niemców, a napotykanych w poniemieckich domach przez osoby, które miały za sobą doświadczenia robót przymusowych w Niemczech bądź przebywania w niemieckich obozach koncentracyjnych.

Andrzej Brencz zrealizował w rejonie środkowej Odry badania etnograficzne, przeprowadzając m.in. wywiady z ludnością, która przybyła na te tereny. Przywołuje on wypowiedź dotyczącą niszczenia niemieckich zabytków: „oczywiście szkoda, że je zniszczono; istniała taka mentalność, to co niemieckie to można było zniszczyć. To samo dotyczy innych rzeczy niemieckich, na przykład kury jadły z kryształowych misek" ${ }^{8}$. Powyższa wypowiedź dobrze ilustruje mentalność osadników, która odzwierciedla się w działaniach podejmowanych w dwóch wymiarach: publicznym i prywatnym. Zabytki funkcjonujące $\mathrm{w}$ przestrzeni publicznej pozostawały przede wszystkim w gestii władz, która często przyzwalała na niszczenie niemieckiego dziedzictwa także przez osoby prywatne ${ }^{9}$. Z nadużyciami, do których dochodziło w ramach akcji „odniemczania”, walczyli często historycy sztuki i konserwatorzy zabytków, którzy starali się ratować to, co się dało. Jednak, jak podkreśla Maria Rutowska, „apeli o nieniszczenie zabytków nie zawsze brano pod uwagę. Dla władz bowiem i większości mieszkańców tych obszarów stanowiły one przede wszystkim "pozosta-

7 C. Caruth, Traumatyczne przebudzenia (Freud, Lacan i etyka pamięci), tłum. K. Bojarska, [w:] Antologia studiów nad traumą, red. T. Łysak, Kraków 2015, s. 31-32.

8 A. Brencz, Oswajanie niemieckiego dziedzictwa kulturowego. Z badań etnograficznych na Środkowym Nadodrzu, [w:] Wokót niemieckiego dziedzictwa..., s. 214.

9 M. Rutowska, Polityk wobec niemieckiej spuścizny kulturowej, [w:] Wspólne dziedzictwo? Ze studiów..., s. 173-174. 
łości niemczyzny«, a więc dbałość o nie była nieuzasadniona” ${ }^{10}$. Przedmioty znajdowane w domach prywatnych, takie jak miski, o których mowa wyżej, odsyłają do codziennych zachowań konkretnych osób w przestrzeni prywatnej. Można zatem zauważyć, że praktyki takie przenosiły się z przestrzeni publicznej w przestrzeń prywatną. Potrzeba unieważnienia i przekreślenia niemieckiego dziedzictwa materialnego, a więc także kulturowego wyrażała się w tym wypadku w prywatnych, jednostkowych działaniach osób, dla których przytoczona powyżej kryształowa miska stawała się symbolem niemieckiej kultury, a oddanie jej kurom — zmianą znaczenia takiego przedmiotu, a być może również sposobem na upokorzenie niemieckiego dziedzictwa. Trafnie pisze o tym Iwona Liżewska:

Pewna wrogość czy w najlepszym wypadku obojętność w stosunku do wszelkich przejawów kultury niemieckiej wynikała z poczucia krzywdy polskiej w czasie okupacji. [...]. Przez wiele lat decydującym argumentem przemawiającym za odbudową czy zachowaniem danego obiektu było określenie go mianem „polski”, w przeciwieństwie do obiektów sklasyfikowanych jako „niemieckie” lub jeszcze częściej — „pruskie”. Przypisanie do tej drugiej grupy często skazywało dany obiekt czy zespół architektury na zagładę lub co najmniej usprawiedliwiało pozostawienie go własnemu losowi ${ }^{11}$.

Na fakt ten zwraca też uwagę Beata Halicka, stwierdzając, że „niemal cała nowa ludność Nadodrza była zgodna co do tego, że oswojenie i zagospodarowanie terenów mogły zakończyć się sukcesem tylko pod warunkiem usunięcia śladów kultury niemieckiej oraz konsekwentnej, dogłębnej "polonizacji« krajobrazu kulturowego"12. Praktyki takie pomagały w rozładowywaniu trudnych emocji ludzi. Jak bowiem zauważa Halicka, „[w]ielu czuło tak silną antypatię do Niemców, że wszystko, co wiązało się z kulturą tego narodu, działało na nich odpychająco"13. Upadek niemieckiej kultury mógł stanowić rekompensatę za doznane krzywdy i oznaczać ich własne, prywatne zwycięstwo. Mentalność, o której mowa w przywołanej wyżej wypowiedzi osadnika, usprawiedliwiająca i jednocześnie traktująca takie działanie jako niszczenie tego, co niemieckie, nie znajdowała pragmatycznych przesłanek, ale zbudowana była na podstawie przesłanek emocjonalnych oraz ideologicznych.

Odreagowywanie traumatycznych doświadczeń mogło odbywać się też przez przywłaszczanie pozostawianych przez Niemców przedmiotów, a niekoniecznie jedynie przez ich destrukcję ${ }^{14}$. Niezwykle wymowny w tym kontekście jest fragment wspomnień Stanisława Dulewicza, burmistrza Darłowa, zatytułowany „Bal maskowy", w którym opisuje on osadników przebierających się w rzeczy znalezione w domu milionera i burmistrza Schifmanna. Dulewicz nie tylko opisuje akty wcześniejszego rozgrabiania przedmiotów pozostawionych w jego willi, lecz także scenę

${ }_{10}$ Ibidem.

11 I. Liżewska, Ochrona dóbr kultury na Warmii i Mazurach, [w:] Wspólne dziedzictwo? Ze studiów..., s. 240.

12 B. Halicka, op. cit., s. 267.

13 Ibidem, s. 266.

14 Na temat traumy wynikającej z doświadczeń II wojny światowej wnikliwie i obszernie pisze Marcin Zaremba w książce Wielka trwoga. Polska 1844-1947, Kraków 2012, s. 87-140. 
odgrywania ról, która miała miejsce w momencie, gdy autor wspomnień znalazł się w tym domu wraz z grupą bliskich osób:

Marysia Kryńska i moja Nika, przybrawszy się w pięknie skrojone ubiory z garderoby Schifmannowej, odgrywały rolę pań domu [...]. Również i „panowie”, idąc za przykładem „pań”, powędrowali do garderoby Schifmanna, by spośród jego strojów dobrać dla siebie odpowiednie. Wśród salw śmiechu, miodowych uśmiechów i z nadmiarem wersalskiej uprzejmości całe „towarzystwo” gustownie ubrane udało się do najpiękniejszego saloniku. Nawet i ja [...] miałem na sobie kurtkę z grubego samodziału w białe i czarne prążki [...]. Mówi się czasem o niektórych książkach: habend sua fata libelli, a ja powinienem powyższe powiedzenie przetrawestować: „Mają i kurtki czasem swoje przeznaczenie”, gdyż tak się rzeczywiście przytrafiło, że kurtka, która okrywała ostatniego niemieckiego burmistrza Schifmanna, przetrwała jego rządy w Darłowie, gdyż przez jakieś pięć lat nosiłem ją również jako pierwszy burmistrz miasta Darłowa ${ }^{15}$.

Cytat ten, opisujący przebieranie się przybyszów, z jednej strony pokazuje, że ironia takich zachowań rozładowywała napięcia upokorzonych wcześniej Polaków, z drugiej świadczy też o świadomości przewrotności historii samych rzeczy. I tak, szczególnie interesujący w przytoczonym powyżej fragmencie, niezwykle sugestywnie zatytułowanym, jest motyw odgrywania ról. Performatywność zarysowanej sceny stanowi dobry przykład tego, w jaki sposób specyficzna zabawa (z) rzeczami umożliwia odreagowanie traumy. Wchodzenie w rolę stwarza w takim wypadku sposobność przepracowania traumatycznego doświadczenia i rekonfiguracji układów społecznych oraz społecznych ról, w które wcześniej wtłoczeni byli ludzie, którzy znaleźli się w opisanej tu sytuacji. Na istotność i rolę możliwości odgrywania na różne sposoby przeszłości zwraca uwagę Marvin Carlson. Analizując klasyczną pracę J.L. Moreno pt. Psychodrama, przywołuje on jego stwierdzenie, że psychodrama daje „możliwość rekapitulacji nierozwiązanych problemów w swobodniejszym, szerszym i bardziej elastycznym otoczeniu społecznym" ${ }^{16}$. Jednocześnie warto też zwrócić uwagę na to, co Dominick LaCapra nazywa żałobną performatywnością, uznając, że może ona stać się „warunkiem koniecznym przepracowania" ${ }^{17}$. Jak zauważa historyk, $\mathrm{w}$ wypadku żałobnego odgrywania mamy do czynienia „z taką relacją wobec przeszłości, która zakłada, że różni się ona od teraźniejszości - to jednocześnie pamiętanie i dystansowanie się wobec przeszłości czy też jej aktywne zapominanie, a przez to dopuszczenie osądu krytycznego i umożliwienie powrotu do życia" ${ }^{18}$. Przeszłość zostaje ożywiona, a jej odgrywanie służy w opisanym wypadku zdystansowaniu się wobec przeszłości, stwarzaniu warunków do krytycznego spojrzenia w przeszłość, a więc w konsekwencji daje możliwość przepracowania traumy. Wejście w role „pań" i „panów” w domu burmistrza Schifmanna stanowiło swoisty powrót do przeszłości à rebours. Było odegraniem i wejściem w określone role, lecz

15 S. Dulewicz, Burmistrz Darłowa, [w:] Mój dom nad Odrą..., s. 189-190. Pierwszy raz pamiętnik ten został opublikowany w Pamiętnikach osadników Ziem Zachodnich na stronach 19-87.

16 Por. M. Carlson, Performans, tłum. E. Kubikowska, Warszawa 2007, s. 76.

17 D. LaCapra, Trauma, nieobecność, utrata, tłum. K. Bojarska, [w:] Antologia studiów..., s. 90-91.

18 Ibidem, s. 90. 
także jednoczesnym odwróceniem i przekształceniem przeszłości. Nie było melancholijnym i kompulsywnym powracaniem do przeżytej traumy, ale jednorazowym, leczniczym performansem przywołującym przeszłość na zasadzie psychodramy, właśnie za pośrednictwem rzeczy, które umożliwiły odegranie opisanej sceny. Garderoba $\mathrm{i}$ inne przedmioty znalezione $\mathrm{w}$ domu byłego burmistrza stanowiły pomost między przeszłością a ówczesną teraźniejszością głównego bohatera wspomnień. To one sprawiły, że potencjalna miniona rzeczywistość byłych mieszkańców tego domu została ożywiona, lecz jednocześnie przetworzona.

W przywołanej tu wypowiedzi Dulewicza istotny jest też wątek przywłaszczania przedmiotów. Rzeczy odrywają się tu bowiem od swoich właścicieli i zyskują odrębną historię i tożsamość - jak to miało miejsce w wypadku przywołanej kurtki. Przekonanie, że nie tylko książki, w myśl zacytowanej łacińskiej sentencji, ale rzeczy w ogóle, posiadają odrębny los, świadczy o nadaniu przez autora owej autobiograficznej wypowiedzi odrębnego znaczenia dziejom rzeczy. Stają się one autonomiczne wobec dziejów swoich właścicieli i często ich „przeżywają”.

Nie zawsze jednak napotykane niemieckie przedmioty służyły za obiekty umożliwiające rozładowanie emocjonalnych napięć. W większości wypadków przyjmowano bowiem inną strategię - strategię wymiany i udomowienia. Pozbywanie się poniemieckich rzeczy bądź ich zagospodarowywanie wiązało się z ubóstwem. Napotykane przedmioty sprzedawano (zastawy, instrumenty, luksusowe meble etc.) bądź wymieniano z braku środków do życia i wszechobecnej, powojennej biedy. Przesiedleńcy nie dysponowali w wystarczającej liczbie własnymi przedmiotami, którymi mogliby wypełnić tę przestrzeń. Niejednokrotnie wyposażenie wnętrz zastanych mieszkań skutkowało zatem pozytywną reakcją. Władysława Pilak, osadniczka na Ziemiach Zachodnich, pisała w swych wspomnieniach o jednym z wrocławskich mieszkań tak: „Było miło i przytulnie. Łóżka nie tylko miały materace, ale i pościel, kilka obrazów na ścianie. Naczynia w kredensie i wszystkie niezbędne sprzęty domowe zastaliśmy w mieszkaniu” 19 . Inny osadnik pisał z kolei: „Udałem się również zobaczyć nasze mieszkanie. Było urządzone możliwie i zaopatrzone we wszystkie najpotrzebniejsze sprzęty. Mogliśmy więc zamieszkać jak u siebie" ${ }^{20}$. Możliwość spokojnego zamieszkania, które nie wiązało się z koniecznością walki o podstawowe przedmioty konieczne do życia, przynosiła niekłamane zadowolenie i satysfakcję, wynikającą $\mathrm{z}$ osobistego komfortu, a nie $\mathrm{z}$ faktu ich porzucenia przez Niemców. To dawało też ważne poczucie zadomowienia i wrażenie „bycia u siebie”, o którym mowa w przytoczonym fragmencie wspomnień. Otaczanie się przedmiotami, niezależnie nawet od tego, jakie było źródło ich pochodzenia, stanowiło niezwykle ważny składnik budowania stabilizacji.

Kwestia zadowolenia $\mathrm{z}$ nabycia poniemieckich przedmiotów była inną, ważną składową historii Polaków na „Ziemiach Odzyskanych”. Szczególnie dostrzegalna

\footnotetext{
19 W. Pilak, „Kocham w nim wszystko, nawet gruzy...”, [w:] Pamiętniki osadników..., s. 148.

${ }^{20}$ Ibidem, s. 129.
} 
była w wypadku wsi. Polacy przybywający z wiejskich terenów wcześniej byli na tyle biedni i dysponowali tak niewielką liczbą przedmiotów, że wypełnienie owej przestrzeni swoimi rzeczami i tak często nie byłoby możliwe. Chętnie korzystano więc z zastanego inwentarza. Cytowany już osadnik, przybywający właśnie do jednej z poniemieckich wsi, pisał tak: „Była to wioska, ale niejedno miasto w dawnych kątach Wileńszczyzny czy Białorusi mogłoby pozazdrościć jej wyglądu, zabudowy i rozmieszczenia"21. W takich wypadkach mamy do czynienia ze specyficzną ambiwalencją wynikającą z jednej strony $\mathrm{z}$ dystansu wobec wrogiej czy obcej kulturowo przestrzeni, czy obcych przedmiotów, z drugiej natomiast - ze specyficznej fascynacji imponującym niejednokrotnie Polakom ze Wschodu, a w szczególności z terenów wiejskich, zaawansowaniem technologicznym czy „cywilizacyjnym” niemieckich miast i wsi. Zderzenie kulturowe doświadczane było zatem wśród wiejskich społeczności przez sam fakt nabycia wielu nieposiadanych wcześniej przedmiotów, jak i, przede wszystkim, za pośrednictwem innej organizacji przestrzeni publicznych, gospodarstw czy samych domów. Różnice te były na tyle podstawowe, że dotyczyły nawet samej materii, budulca, z którego wykonane były domy czy obory. Tu — kamienne, postrzegane wówczas jako bardziej trwałe i stabilne, na wschodzie natomiast przede wszystkim drewniane, uznawane za skromniejsze.

Jednocześnie wiele przedmiotów znajdujących się w gospodarstwach i domach poniemieckich niszczało z powodu ich ignorowania, braku wiedzy i umiejętności ich wykorzystania oraz z powodu różnic, które występowały między poniemieckimi a polskimi wsiami kresów wschodnich, a także z powodu niechęci przyjęcia innego modelu funkcjonowania, który dany przedmiot narzucał, a nie z powodu intencjonalnej chęci jego zniszczenia. W Pamiętnikach osadników Ziem Odzyskanych można znaleźć wiele przykładów takiego zaniedbania. Aleksander Pietraszko pisze na przykład tak:

Spora część ludzi, którzy osiedlili się na zachodzie, pochodziła zza Bugu, gdzie panowało zacofanie i ciemnota, a dlatego w większości wypadków nie mieli pojęcia o technice i elektryczności. Niejednokrotnie nie wiedzieli do czego służą poszczególne przedmioty lub maszyny [...]. Często cenne przedmioty poniewierały się po śmietnikach lub stanowiły zabawkę dla dzieci. Kiedy się o tym przekonałem, to przy każdej kupce śmieci przystawałem i przyglądałem się, czy nie znajdę czegoś pożytecznego. $\mathrm{W}$ ten sposób znalazłem piękny statyw do aparatu fotograficznego i powiększalnik, co w sumie warte jest kilkaset złotych. Przechodząc raz ulicą zauważyłem, jak dzieci ciągnęły odkurzacz elektryczny. Pytam się więc, co one ciągną — Pieska prowadzimy — powiadają $[\ldots]^{22}$.

Wypowiedzi Pietraszki, nacechowane skądinąd negatywnym stosunkiem do ludności ze Wschodu i uruchamiające degradujące mechanizmy Saidowskiego orientalizowania przybyszy z tych rejonów, na poziomie faktografii uświadamiają, że zniszczenie przedmiotów, które na co dzień można było obserwować na terenach tzw. Ziem Odzyskanych, często nie miało nic wspólnego ze świadomym unicestwia-

21 J. Krukowski, Wójt w Św. Katarzynie, [w:] Pamiętniki osadników..., s. 127.

22 A. Pietraszko, Osadnik wojskowy, [w:] Pamiętniki osadników..., s. 296-297. 
niem niemieckiego dziedzictwa materialnego, ale niemożnością lub brakiem umiejętności ich zastosowania. W ten sposób stopniowemu rozkładowi czy dewastacji uległy obiekty, w szczególności na wsiach, które nie były wykorzystywane przez rolników. Jednocześnie nowi mieszkańcy tych terenów często nie chcieli zmieniać swych wcześniejszych zwyczajów kulturowych i dostosować działań do zastanej infrastruktury.

Materialne środowisko, które wyznaczało przestrzeń życia prywatnego przybyszów, było więc także świadomie ignorowane. Wiele przedmiotów było zwyczajnie lekceważonych. Dobitnym przykładem takiego świadomego pomijania ich istnienia było na wsiach niekorzystanie $\mathrm{z}$ drzwi frontowych w poniemieckich domach. Przesiedleńcy, zgodnie z kulturowym zwyczajem pochodzącym z ich stron, używali wejścia do domów od podwórza, a niemieckie, frontowe wejścia uznawali za nieistniejące (później zresztą niejednokrotnie je zabudowywali). Ignorowanie niemieckich rzeczy mogło więc wynikać ze zwyczajnej potrzeby udomowienia i naturalnego przenoszenia modeli kulturowych przybyszy na nowy grunt.

$* * *$

Omówione strategie działań podejmowanych wobec niemieckiej materialnej spuścizny „Ziem Odzyskanych” miały swoje wymierne konsekwencje kulturowe. Powodowana ignorancją lub świadomie podejmowana decyzja dotycząca tego, czego się pozbyć, a co zachować, nie pozostawała bez znaczenia w kontekście formowania tożsamości ludzi wkraczających w obcą przestrzeń. Znaczenie tych decyzji mogło jednak wykraczać daleko poza spodziewane konsekwencje. Rzeczy bowiem stanowią istotny nośnik tożsamości. Są przedmiotami, które niosą w sobie pamięć osobistą i pamięć kulturową. W momencie, w którym pozbywamy się części rzeczy, pozbywamy się też pamięci, która nie tylko dotyczy funkcjonalności przedmiotów, lecz przede wszystkim powoduje zanikanie więzi, jaką z danym przedmiotem stworzyliśmy. Przedmioty bowiem, jak słusznie podkreśla Marek Krajewski, sprawiają, że stajemy się istotami społecznymi, lecz także konkretnym indywiduum ${ }^{23}$. To, co posiadamy, nie tylko świadczy o naszym statusie społecznym, ale też o naszych gustach, preferencjach, światopoglądzie. Odcięcie od owych rzeczy oznacza zatem specyficzną amputację części tożsamości.

W planie społecznym rzeczy zarówno pomagają wytwarzać więzi społeczne, jak i same socjalizują. Jak zauważa Krajewski, „przedmioty stanowiące kontekst procesów socjalizacyjnych nie biorą się znikąd, [...] stanowią materialny zapis kultury i życia społecznego, które odpowiedzialne są za ich stworzenie"24. Bez nich zatem przestajemy być istotami społecznymi, znika bowiem kultura, w której rzeczy

${ }^{23}$ M. Krajewski, Szkice z socjologii przedmiotów, Warszawa 2013, s. 58-61.

${ }^{24}$ Ibidem, s. 53. 
pośredniczą. Warto też zwrócić uwagę, że są one atrybutami czyniącymi nas osobami wypełniającymi określone, społeczne role. W tym właśnie ujawnia się m.in. ich sprawczość. Jak podkreśla badacz kulturowego życia rzeczy, Bjørnar Olsen, „nawet jeśli sprawczość człowieka jest "prymarna«, zawsze dokonuje się ona w świecie materialnym: intencjonalne działanie byłoby niemożliwe bez rzeczy" ${ }^{25}$. Społeczna sprawczość rzeczy oznacza więc konieczność otaczania się nimi i posiadania ich, by móc stać się istotą społeczną. Bez długopisu, kartki czy komputera nie można być współcześnie pisarzem czy pisarką.

Decyzja o zachowaniu wybranych poniemieckich przedmiotów oznaczała zatem także zachowanie czy przechowanie części tożsamości i pamięci ludzi, którzy wcześniej wytworzyli lub posiadali takie przedmioty. Oznaczała też akceptację i przyjęcie modelu funkcjonalności narzucanego przez te przedmioty, a co za tym idzie wpływała nieco na tożsamość przybyszów i formowała ich kulturę. Decyzja o zniszczeniu bądź pozbyciu się wybranych rzeczy wiązała się z kolei z odrzuceniem części niemieckiego dziedzictwa traktowanego bądź jako świadectwo wroga, bądź jako zwyczajnie niepotrzebne. Wtedy to niechciane przedmioty zaczynały pełnić funkcję przeszkód - kłopotu, czegoś niewygodnego, czego trzeba się pozbyć. Ich sprawczość przejawiała się więc w konieczności podjęcia przez ludzi działań na rzecz ich usunięcia, zatarcia.

Ponadto, warto pamiętać, iż tereny poniemieckie nie były zasiedlane w proporcji 1:1. W związku z tym wiele domów nie zostało zamieszkanych w ogóle, ich istnienie sprowadzało się do stopniowego popadania w ruinę, szabrowania oraz ich rozkładu do poziomu pierwotnej materii. Domy przestawały być zatem domami, a stawały się materiałem (cegłami, drewnem), które sprzedawano lub wykorzystywano do budowy czy odbudowy innych budynków. Rozkradanie pozostawionych przez Niemców przedmiotów czy wyposażenia wnętrz nie było zresztą zazwyczaj traktowane zaraz po wojnie jak pospolita kradzież, ale stanowiło normalną i powszechną praktykę umożliwiającą przetrwanie, działanie pragmatyczne i niewywołującą powszechnie zgorszenia. Maria Rutowska pisze nawet o swoistej karierze, jaką zrobiło wtedy słowo „szaber”. Jak pisze: „Szabrowano wszystko co uznano za potrzebne, wartościowe oraz co dało się zabrać, $w$ tym również dzieła sztuki i rzemiosła artystycznego. Skala zjawiska była ogromna"26.

W tym miejscu dotykamy kwestii, w której nakładają się na siebie ponownie dwie płaszczyzny: publiczna i prywatna. W przestrzeni publicznej sposoby radzenia sobie z materialnym dziedzictwem niemieckim były bardziej jednoznaczne i wyraziste. Przede wszystkim podejmowano decyzje o charakterze politycznym, które miały kształtować powszechną tożsamość Polaków żyjących na "Ziemiach Odzyskanych”

25 B. Olsen, W obronie rzeczy. Archeologia i ontologia przedmiotów, tłum. B. Mądra-Shallcross, Warszawa 2013, s. 210.

26 M. Rutowska, Elementy polityki wobec niemieckiej spuścizny kulturowej na Ziemiach Zachodnich i Pólnocnych (1945-1950), [w:] Wspólne dziedzictwo? Ze studiów..., s. 171. Por. też M. Zaremba, Wielka trwoga. Polska 1944-1947. Ludowa reakcja na kryzys, Kraków 2012 czy B. Halicka, op. cit., s. 220-226. 
przez możliwie dogłębne wyeliminowanie śladów niemieckiej kultury i obecności Niemców na tych terenach ${ }^{27}$. Niszczenie niemieckiego dziedzictwa czy grabieże przenosiły się więc również w przestrzeń publiczną, często bez konsekwencji dla sprawców dewastujących niemieckie zabytki. Jednocześnie podejmowano wiele uchwał nakładających na Polaków obowiązek niszczenia i zamalowywania niemieckich napisów etc. znajdujących się w przestrzeni publicznej. Strategia niszczenia dotyczyła zresztą przede wszystkim niszczenia niemieckich pomników czy tablic pamiątkowych.

O niemieckim dziedzictwie świadczyły jednak nie tylko przedmioty czy monumenty, których celem było upamiętnienie, lecz także sama niemiecka architektura czy nawet układ urbanistyczny. W tym wypadku podstawowe założenie dotyczyło nieodbudowywania zburzonych budynków bądź - gdy były na to środki - rozbiórki i niszczenia niemieckiej architektury, szczególnie wówczas gdy reprezentowała ona niemiecką dominację na tych terenach (chodzi tu o budynki zbudowane w neogotyckim stylu, siedziby i rezydencje niemieckich władz etc.). Stopniowe popadnie w ruinę, rozkład budynków, szabrowanie ich było dostrzegalne gołym okiem. Stanowiło znak i wyraz pożądanej degradacji, poniżenia i dewastacji niemieckiego dziedzictwa, dokonujących się na oczach Polaków. Proces rujnacji odgrywał tu zatem kolejną, istotną rolę w przekształcaniu tożsamości przestrzeni publicznej „Ziem Odzyskanych"28.

Praktyki te stanowiły ważny element strategii zmiany znaczenia omawianych terenów. Nie były jednak wystarczające. Bardzo ważnym czynnikiem ich oswajania było bowiem nadbudowanie zastanej i narzuconej przestrzeni polskimi treściami. W tych działaniach przejawiała się specyficzna próba skolonizowania poniemieckiego terytorium. Kwestia ta mocno się niestety komplikuje, gdyż praktyki nadawania nowego znaczenia przestrzeni publicznej poprzez budowanie pomników, nazywanie ulic czy wznoszenie nowej architektury naznaczone były tu nową zależnością, w której znaleźli się Polacy wraz z włączeniem Polski w sowiecką strefę wpływów. Spolszczanie niemieckiej przestrzeni uzależnione było zatem od sowieckiej wizji politycznej podległych państw satelickich. Problem ten stanowi osobny i interesujący temat rozważań, na który nie ma tu miejsca. Pragnę jednak zaznaczyć, że w wypadku strategii oswajania poniemieckiej przestrzeni publicznej, podejmowanych wtedy także przez Polaków, powszechną praktyką było aktywne wpływanie na kształt tej

27 Zadziwia niezwykła skuteczność praktyk anihilowania świadomości niemieckości omawianych tu obszarów. Z perspektywy ponad 70 już lat od przejęcia przez Polskę tych obszarów widać, jak nikła jest wiedza młodych Polaków dotycząca niemieckiej obecności na tych terenach. Por. G. Talko, A. Kokiel, Niemiecki Szczecin Polaków?, [w:] Dom Otwarty/Dom Zamknięty? II. Pogranicza wobec różnicy, red. Izabela Skórzyńska, Poznań 2014, s. 49-66.

28 Dobitnie pisze o tym Jan Musekamp w swej doskonałej pracy o Szczecinie w rozdziale „Zabytki - między polonizacją a rozbiórką", s. 259-263 n. Por. idem, Między Stettinem a Szczecinem. Metamorfozy miasta od 1945 do 2005, tłum. J. Dąbrowski, Poznań 2013. Inną świetną pracą traktującą m.in. o tych kwestiach jest książka Gregora Thuma, Obce miasto. Wrocław 1945 i potem, tłum. M. Słabicka, Wrocław 2006. 
przestrzeni poprzez tzw. repolonizację i swoiste „znaczenie” poniemieckiego terytorium treściami wskazującymi na inną relację podległości i zależności.

\section{Podsumowanie}

Podsumowując, należy stwierdzić, że niemieckie dziedzictwo materialne na terenach „Ziem Odzyskanych” wymagało od polskich przesiedleńców podjęcia wielu działań zarówno w przestrzeni prywatnej, jak i w przestrzeni publicznej. Stanowiło ważny element przepracowywania wojennej traumy w związku z możliwością jej odreagowania ujawniającego się w niszczeniu osobistych przedmiotów pozostawionych przez Niemców w ich domach oraz przez destrukcję i rujnację, jaka dokonywała się wobec niemieckiego dziedzictwa kulturowego w przestrzeni publicznej.

Konfrontacja z zastaną sferą materialną wymagała podjęcia wielu działań umożliwiających oswojenie i zamieszkanie na terenach obcych i wrogich. Owe działania koncentrowały się wokół kilku podstawowych strategii radzenia sobie z „narzuconą przestrzenią", takich jak np. możliwość decydowania o tym, jakie przedmioty włączone zostały w nowy obieg kulturowy, a jakie miały zostać zniszczone. Które z nich ignorowano, a które udomawiano. Wszystkie te, mniej lub bardziej udane, próby oswajania niemieckości nowo nabytych ziem świadczyły o sprawczości rzeczy, która widoczna była zarówno gdy funkcjonowały one jako przedmioty — przeszkody, jak i gdy stanowiły przedmioty, nośniki funkcjonalności i tożsamości kulturowej. Ludzie zmuszeni byli bowiem do podejmowania wielu działań wobec rzeczy. Stanowiły one istotny element wytwarzania nowej społecznej i prywatnej przestrzeni życia Polaków na poniemieckim terytorium.

\section{Bibliografia}

Brencz A., Oswajanie niemieckiego dziedzictwa kulturowego. Z badań etnograficznych na Środkowym Nadodrzu, [w:] Wokót niemieckiego dziedzictwa kulturowego na Ziemiach Zachodnich i Pótnocnych, red. Z. Mazur, Instytut Zachodni, Poznań 1997, s. 191-216.

Carlson M., Performans, tłum. E. Kubikowska, Wydawnictwo Naukowe PWN, Warszawa 2007.

Caruth C., Traumatyczne przebudzenia (Freud, Lacan i etyka pamięci), thum. K. Bojarska, [w:] Antologia studiów nad traumą, red. T. Łysak, Universitas, Kraków 2015, s. 31-57.

Dulewicz S., Burmistrz Darłowa, [w:] Mój dom nad Odrą. Pamiętniki osadników Ziem Zachodnich po 1945 roku, red. B. Halicka, Universitas, Kraków 2016, s. 146-213.

Halicka B., Polski Dziki Zachód. Przymusowe migracje i kulturowe oswajanie Nadodrza 1945-1948, Universitas, Kraków 2015.

Jankowiak S., Wysiedlenie i emigracja ludności niemieckiej w polityce władz polskich w latach 1945-1970, Instytut Pamięci Narodowej, Warszawa 2005.

Jasiewicz Z., Badania na ziemiach zachodnich i pótnocnych i ich znaczenie dla etnologii polskiej, [w:] Polska-Niemcy. Pogranicze kulturowe i etniczne, red. M. Buchowski, A. Brencz, Polskie Towarzystwo Ludoznawcze, Wydawnictwo Poznańskie, Wrocław-Poznań 2004 s. 39-54.

Miscellanea Posttotalitariana Wratislaviensia 6/2017

(C) for this edition by CNS 
Krajewski M., Szkice z socjologii przedmiotów, Fundacja Nowej Kultury Bęc Zmiana, Warszawa 2013.

Krukowski J., Wójt w Św. Katarzynie, [w:] Pamiętniki osadników Ziem Odzyskanych, red. Z. Dulczewski, A. Kwilecki, Wydawnictwo Poznańskie, Poznań 1970 s. 124-138.

LaCapra D., Trauma, nieobecność, utrata, tłum. K. Bojarska, [w:] Antologia studiów nad traumą, red. T. Łysak, Universitas, Kraków 2015, s. 59-107.

Latour B., From realipolitik to dingpolitik or how to make things publick, [w:] Making Things Public. Atmosphere of Democracy, red. B. Latour, P. Weibel, Massachusetts- Karlsruhe 2005, s. 4-31.

Latour B., Splatajac na nowo to, co społeczne: wprowadzenie do teorii aktora-sieci, tłum. A. Derra, K. Abriszewski, Universitas, Kraków 2010.

Liżewska I., Zabytki w naszych rękach. O ochronie dóbr kultury na Warmii i Mazurach w latach 19451989, [w:] Wspólne dziedzictwo? Ze studiów nad stosunkiem do spuścizny kulturowej na Ziemiach Zachodnich i Pótnocnych, red. Z. Mazur, Instytut Zachodni, Poznań 2000, s. 239-265.

Mądra-Shallcross B., Rzeczy i Zagłada, Universitas, Kraków 2010.

Misztal J., Wysiedlenia i repatriacja obywateli Polskich $z$ ZSRR a wysiedlenia i przesiedlenia Niemców $z$ Polski - próba bilansu, [w:] Utracona ojczyzna, red. H. Orłowski, A. Sakson, Instytut Zachodni, Poznań 1996, s. 45-74.

Musekamp J., Między Stettinem a Szczecinem. Metamorfozy miasta od 1945 do 2005, tłum. J. Dąbrowski, Wydawnictwo Nauka i Innowacje, Poznań 2013.

Olsen B., W obronie rzeczy. Archeologia i ontologia przedmiotów, tłum. B. Mądra-Shallcross, Wydawnictwo IBL PAN, Warszawa 2013.

Pietraszko A., Osadnik wojskowy, [w:] Pamiętniki osadników Ziem Odzyskanych, red. Z. Dulczewski, A. Kwilecki, Wydawnictwo Poznańskie, Poznań 1970, s. 291-301.

Pilak W., „Kocham w nim wszystko, nawet gruzy...”, [w:] Pamiętniki osadników Ziem Odzyskanych, red. Z. Dulczewski, A. Kwilecki, Wydawnictwo Poznańskie, Poznań 1970, s. 139-152.

Rutowska M., Elementy polityki wobec niemieckiej spuścizny kulturowej na Ziemiach Zachodnich i Pótnocnych (1945-1950), [w:] Wspólne dziedzictwo? Ze studiów nad stosunkiem do spuścizny kulturowej na Ziemiach Zachodnich i Pótnocnych, red. Z. Mazur, Instytut Zachodni, Poznań 2000, s. 167-200.

Rzeczy i ludzie. Humanistyka wobec materialności, red. J. Kowalewski, W. Piasek, M. Śliwa, Instytut Filozofii Uniwersytetu Warmińsko-Mazurskiego, Olsztyn 2008.

Stola D., Wielkie migracje w Europie XX wieku, [w:] Cywilizacja europejska. Eseje i szkice z dziejów cywilizacji i dyplomacji, red. M. Koźmiański, Instytut Historii PAN, Warszawa 2010 s. 355-375.

Talko G., Kokiel A., Niemiecki Szczecin Polaków? [w:] Dom Otwarty/Dom Zamknięty? II. Pogranicza wobec różnicy, red. I. Skórzyńska, Instytut Historii UAM, Poznań 2014, s. 49-66.

Thum G., Obce miasto. Wrocław 1945 i potem, tłum. M. Słabicka, Via Nova, Wrocław 2006.

Wokół niemieckiego dziedzictwa kulturowego na Ziemiach Zachodnich i Północnych, red. Z. Mazur, Instytut Zachodni, Poznań 1997.

Wspólne dziedzictwo? Ze studiów nad stosunkiem do spuścizny kulturowej na Ziemiach Zachodnich i Pótnocnych, red. Z. Mazur, Instytut Zachodni, Poznań 2000.

Zaremba M., Wielka trwoga. Polska 1944-1947, Ludowa reakcja na kryzys, Znak, Kraków 2012.

\section{Przyjęto do druku/Accepted for publication: 5.03.2017}

